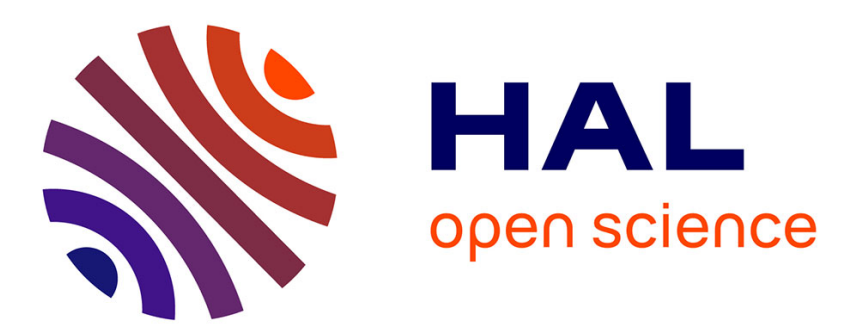

\title{
Accounting for the Gaps in Labour Standard Compliance: The Role of Reputation-Conscious Buyers in the Cambodian Garment Industry \\ Chikako Oka
}

\section{- To cite this version:}

Chikako Oka. Accounting for the Gaps in Labour Standard Compliance: The Role of ReputationConscious Buyers in the Cambodian Garment Industry. European Journal of Development Research, 2010, 22 (1), pp.59-78. 10.1057/ejdr.2009.38 . hal-02952241

\section{HAL Id: hal-02952241 https://hal.science/hal-02952241}

Submitted on 25 Mar 2021

HAL is a multi-disciplinary open access archive for the deposit and dissemination of scientific research documents, whether they are published or not. The documents may come from teaching and research institutions in France or abroad, or from public or private research centers.
L'archive ouverte pluridisciplinaire HAL, est destinée au dépôt et à la diffusion de documents scientifiques de niveau recherche, publiés ou non, émanant des établissements d'enseignement et de recherche français ou étrangers, des laboratoires publics ou privés. 


\title{
Accounting for the Gaps in Labour Standard Compliance: The Role of Reputation-Conscious Buyers in the Cambodian Garment Industry
}

\author{
Chikako Oka
}

Working conditions in global supply chains have come under increased public scrutiny. Faced with this growing demand for accountability, some multinational enterprises have come to play regulatory roles in developing countries where they do business. This paper combines quantitative and qualitative methods to examine the effects of reputation-conscious buyers on supplier labour standard compliance in the Cambodian garment sector. Using unique factory-level panel data, this paper shows that factories producing for reputation-conscious buyers are associated with better compliance levels than other factories, controlling for factory characteristics. Fieldbased interviews also demonstrate that reputation-conscious buyers regulate supplier compliance both 'reactively' and 'proactively.' The findings shed light on the opportunities and limits of buyer-driven regulation. 


\section{INTRODUCTION}

Business has come to play an important role in regulating the sphere traditionally reserved for government, especially in developing countries. On the one hand, the globalisation of production and the vertical disintegration of multinational enterprises (MNEs) have contributed to the growing industrial capabilities in the developing world (Gereffi et al., 2005). On the other hand, persistent lack of capacity of developing country governments has created regulatory gaps, and transnational networks of activists have come to demand MNEs to assume responsibilities for regulating labour conditions in their supply chains (Elliott and Freeman, 2003).

In particular, MNEs in labour-intensive sectors such as garment and footwear have been criticised for sourcing from countries where labour is cheap and regulation is weak: taking advantage of so-called "sweatshop" labour and aggravating a "race to the bottom." The 1990s saw a remarkable growth in anti-sweatshop campaigns, mostly emanating from the United States and Europe. In particular, famous brands such as the Gap, Levi Strauss, and Nike were exposed and blamed for dismal working conditions in their supply chains in developing countries.

As a response to the growing demand for more proactive involvement in regulating working conditions, many MNEs have implemented codes of conduct ( $\mathrm{CoC})$ and monitoring procedures while some brands have joined multi-stakeholder initiatives (MSI) to commit to better working conditions in global supply chains (O'Rourke, 2006). The principal motivation of MNEs is to safeguard their reputation as damaging a brand image incurs a considerable financial loss (Conroy, 2007). To a larger extent, therefore, non-state regulation 
has become one of the dominant modes of regulating labour conditions in global supply chains.

The rise of non-state regulation of labour standards has provoked heated debates about its effectiveness. While some see $\mathrm{CoC}$ and private monitoring as a flexible response to the reality of poor regulation in developing countries (Nadvi and Waltring, 2004), others criticise the narrow scope of $\mathrm{CoC}$, conflict of interests inherent in private monitoring, and lack of worker involvement (Jenkins et al., 2002; Esbanshade, 2004). Moreover, Elliott and Freeman (2003) voice concerns that anti-sweatshop campaigns' focus on brands restricts the regulated realm to export sector for brand products whereas working conditions elsewhere tend to be worse. Similarly, Seidman (2008) points out that under the private system of CoC and monitoring, buyers choose the level of standards for their target consumers: US brands targeting students such as the Gap may implement rigorous standards while retailers targeting price-conscious consumers such as Wal-Mart may care less.

This last point raises an important question about the potential and limits of buyer-driven regulation. Do different buyers have different labour standards? Do reputation-conscious buyers regulate suppliers differently from other buyers? Does buyer-driven regulation create pockets of best practices or ratchet up working conditions? These questions remain largely unanswered mainly due to lack of systematic data.

The purpose of this paper, therefore, is two fold: (i) to assess whether buyers with different degrees of reputation consciousness - defined in this paper using buyers' MSI membership status - variably influence supplier compliance with labour standards and (ii) to identify the patterns through which buyers regulate working conditions in supplier factories. This article 
seeks to achieve this task through a mix of quantitative and qualitative approaches. Quantitative analysis exploits the unique factory-level data provided by the International Labour Organization (ILO) programme, Better Factories Cambodia (BFC). Qualitative analysis is based on the author's field research conducted in Phnom Penh, Cambodia in the summers of 2007 and 2008.

This article is organised as follows. The next section introduces the empirical literature concerning buyer influence on supplier working conditions, followed by the background on Cambodia's garment sector. The theory section links the motivations of buyers and suppliers with compliance performance. Then, the methods and data will be discussed. The quantitative section shows that factories producing for reputation-conscious buyers have better compliance levels than other factories. The qualitative section demonstrates that reputationconscious buyers enforce labour standards both reactively and proactively while suppliers also make proactive efforts despite constraints imposed by purchasing practices. Finally, the article concludes by highlighting the potential and limits of buyer-driven regulation and the actions needed to spread the benefits of better working conditions more widely.

\section{BUYER INFLUENCE ON SUPPLIER WORKING CONDITIONS}

The growing empirical literature on buyer influence on supplier working conditions can be broadly divided into two strands: the first strand critically evaluates buyer $\mathrm{CoC}$, monitoring, and various initiatives to regulate labour conditions while the other strand focuses on particular buyers and/or buyer-supplier relationships. 
Jenkins et al. (2002) and Barrientos et al. (2003) criticise buyer CoC for their narrow scope and bias against labour rights such as freedom of association. Moreover, Esbanshade (2004) and Seidman (2008) find fault with private monitoring that excludes workers and lacks transparency and credibility. Hence, scholars in this camp emphasise the need to empower workers and argue for stronger national regulation. On the other hand, the weakness of this strand of the literature lies in a lack of quantitative assessment.

The most comprehensive evaluation of MSI to date is the impact assessment study of the Ethical Trading Initiative (ETI), a UK-based MSI. Based on the study, Barrientos and Smith (2007) point out that despite some progress on outcome standards that are visible and easily codified (e.g. safety and health, minimum wage), the ETI base code had little or no impact on process rights that enable workers to negotiate and access to their own entitlements (e.g. freedom of association). Despite the large-scale study covering 11 ETI member companies, 23 supplier sites in 5 countries, the impacts are not assessed quantitatively. Moreover, they do not compare suppliers of ETI member companies with other suppliers, limiting the types of buyers under examination.

In the other strand of the literature, empirical studies have largely been case studies of branded buyers. Frenkel (2001) studies two global athletic footwear brands and their contractor factories in China and describes how brands shape employment relations in their suppliers. Through a matched-pair case study, Frenkel and Scott (2002) examine two otherwise similar Adidas suppliers and explain the difference in working conditions by their relationships with Adidas: one enjoyed a collaborative relationship while the other was kept at arm's length. They conclude that a close and collaborative relationship with Adidas has encouraged value-sharing, learning, and innovation, contributing to better working conditions. 
In a similar case study of Nike and its suppliers, Locke and Romis (2006) reach a similar conclusion.

In a rare quantitative treatment of the subject, Locke et al. (2007) systematically assess the determinants of Nike's internal monitoring scores covering 830 suppliers in 51 countries. They find that factories designated as Nike's "strategic partners" and those frequently visited by Nike's staff have higher compliance scores. Moreover, Jiang (2009) demonstrates a statistically significant link between the nature of buyer-supplier relationships and supplier compliance with $\mathrm{CoC}$, based on survey data from China's garment industry. Nonetheless, Nike's study is limited by their exclusive focus on one brand while Jiang (2009) does not differentiate the types of buyers, precluding comparison of buyers.

In sum, both strands of the literature lack a systematic assessment of whether and how different types of buyers variably affect supplier working conditions. This study seeks to fill the gap by examining how buyers with different degrees of reputation consciousness influence labour standard compliance in Cambodia's garment sector.

\section{THE ILO MONITORING PROGRAMME IN CAMBODIA'S GARMENT SECTOR}

Cambodia's garment sector has been undergoing an innovative experiment to improve working conditions. All exporting garment factories are required by the Cambodian government to submit to regular monitoring by the International Labour Organization (ILO) programme called Better Factories Cambodia (BFC). In fact, this ILO monitoring programme grew out of the 1999 US-Cambodia bilateral trade agreement, in which an increase in a quota (i.e. access to the US market) was conditioned upon significant improvements in working 
conditions (Polaski, 2006). The ILO was asked to monitor and report progress in the industrywide labour compliance level, which was then used by the US government to determine quota increases and subsequently by buyers for sourcing decisions (Kolben, 2004). The Cambodian government has come to see the ILO monitoring scheme as a niche strategy to attract reputation-conscious buyers while these buyers have come to appreciate ILO monitoring as a stamp of approval. This explains why the ILO monitoring programme has been renewed even after the expiration of the quota regime at the end of $2004 .^{1}$

Compared to private monitoring often criticised for its ineffectiveness and conflict of interests, monitoring by the ILO enjoys important advantages. First, unlike audit firms dependent on factories they audit for revenues, the ILO programme is not directly paid by monitored factories, which helps maintain its impartiality. ${ }^{2}$ Second, unlike some commercial auditors detached from local contexts and unable to speak directly to local stakeholders, ILO monitors are locally hired Cambodian nationals who speak the language and understand the local context, increasing their sensitivity and effectiveness as monitors. Third, ILO monitors are hired through competitive procedures, extensively trained, and well-equipped, helping ensure the quality of monitoring.

This paper focuses on the unique nature of the Cambodian model that combines semi-public monitoring and private enforcement. While the ILO is mandated to monitor and report factory compliance with the Cambodian labour law and international labour standards, the ILO has no enforcement power. The Ministry in charge of labour inspection and remediation suffers from incapacity and corruption, which prevents it from effectively enforcing the labour law. Given the lack of government enforcement, buyers often act as a virtual enforcement authority. ILO monitoring reports are accessible to buyers participating in BFC, 
and buyers demand corrective action from suppliers when important violations are found in the ILO monitoring reports.

The Cambodian case provides an excellent opportunity to further our understanding about the role of buyers in regulating labour standards. Cambodia's labour law is one of the most progressive ones in the region, encompassing all the basic international norms such as freedom of association and the right to collective bargaining. As mentioned earlier, ILO monitoring is more independent and credible than private auditing. Furthermore, the industrywide monitoring and other factory-level data collected by ILO BFC enable a quantitative assessment of determinants of supplier compliance. All in all, examining the Cambodian case enables us to go beyond the quality of $\mathrm{CoC}$ and monitoring and focus on whether and how different types of buyers regulate suppliers differently.

\section{THEORY AND HYPOTHESES}

Theoretical literature on compliance has traditionally focused on the role of enforcement and deterrence. The literature has been inspired by the economics of crime literature pioneered by Becker (1968) and Stigler (1970), who argued that individuals and firms weigh the cost and benefit of non-compliance when deciding whether or not to violate a law. This deterrence theory posits that a firm's propensity to comply with regulations is positively related with the probability of detection and expected penalty of violation. In other words, unless detection is probable and punishment is sufficiently severe, firms always have an incentive to evade regulation. This logic has been applied to a number of compliance issues including occupational safety and health (Viscusi, 1979) and minimum wage compliance (Ashenfelter and Smith, 1979). More recently, this theory has been applied to private monitoring of 
minimum wage compliance in the US garment industry (Weil, 2005; Weil and Mallo, 2007). They find that more stringent forms of monitoring by manufacturers are associated with better compliance.

While labour standard compliance directly concerns factories, the deterrence theory of compliance can explain buyer behaviour as well. Those buyers who face a higher probability of detection and expected penalty are more willing to invest their time and resources in regulating their supply chains than other buyers. Expected penalty is higher for those buyers that derive much of their value from brand image. For major apparel brands such as Adidas, the Gap, and Nike, brand value accounts for 40 to 50 percent of the companies' market capitalisation (Conroy, 2007). Bad publicity arising from negative campaigns seriously damages brand reputation and thus profits. Knowing the vulnerability of brands, activists have deliberately targeted them and often succeeded in modifying corporate behaviour (Ibid.). Given the higher probability of detection and expected penalty, buyers who have the most to lose from bad publicity have come to regulate their supply chains more rigorously.

Most buyers enforce $\mathrm{CoC}$ in their supply chains through pre-order selection and post-order monitoring. Before placing orders, almost all buyers assess the compliance levels of candidate factories either by internal compliance teams or external auditors. If compliance level is deemed unsatisfactory, compliance teams demand corrective action plans. Only when the factory's compliance reaches an acceptable level, can sourcing teams place orders. In this way, buyers' compliance departments play the role of a gate keeper. After orders are placed, factories are regularly monitored, and once important or persistent non-compliance issues are signalled, buyers ask for corrective action plans. If factories do not rectify the problems within a given time frame, buyers may cancel orders. While most major buyers have CoC 
that include the national labour law and international core labour standards, the acceptable level of compliance and the degree of actual enforcement are likely to depend on buyers' vulnerability to negative publicity and thus reputation consciousness.

For supplier factories, therefore, the expected cost of labour standard violation varies with the type of buyers they are producing for. Reputation-conscious buyers, facing the higher expected cost of non-enforcement, are more likely to carefully assess their supplier compliance before placing orders and enforce rigorously after placing orders. Consequently, the cost of non-compliance facing suppliers of reputation-conscious buyers is higher than that of other suppliers, making the former more likely to comply with labour standards than the latter.

The expected cost of non-compliance may also depend on the number of buyers a factory is producing for. From the deterrence perspective, when a factory is being watched by a number of buyers, non-compliance is more likely to be detected and punished, raising the cost of noncompliance. Based on the ETI impact study, Barrientos and Smith (2007:720) point out the importance of "critical mass" of buyers for inducing supplier compliance. Nonetheless, when a factory is producing for only one buyer, the probability of detection may be lower, but the cost of punishment (i.e. eventual cancellation of orders) may be larger. The cost calculation of suppliers, then, is likely to depend on a combination of the type and number of buyers: when a factory is producing for only one or a small number of very reputation-conscious buyers, given their rigorous enforcement and potentially high cost of punishment, the factory is likely to maintain a relatively high level of compliance. When a factory is producing for only one or a small number of less reputation-conscious buyers, however, it is unlikely to give a sufficient incentive for suppliers to improve compliance performance significantly. In 
other words, the effect of critical mass is likely to be more important for less reputationconscious buyers. Given the above discussion, we can form the following hypotheses.

Hypothesis I. Factories producing for at least one particularly reputation-conscious buyer will have a higher level of labour standard compliance than factories producing for other types of buyers.

Hypothesis II. Factories producing for a larger number of less reputation-conscious buyers will have a higher level of labour standard compliance than factories producing for fewer of these buyers.

\section{MIXED METHODS}

This paper combines quantitative and qualitative methods as each method can make distinct contributions (Brady and Collier, 2004). The quantitative method helps establish statistical relationships between variables and an outcome and identify whether and how much each variable matters for the outcome. The qualitative method can account for the causal mechanisms and processes: why and how those variables lead to the outcome. Moreover, triangulation of different methods approaching the same problem increases inferential leverage and enhances the validity of hypotheses (Ibid.).

Specifically, the following quantitative section describes variables and estimates regression models to explain variation in compliance performance of Cambodia's garment factories. The purpose here is to evaluate the hypotheses that reputation consciousness of buyers and the number of such buyers sourcing from a factory significantly affect supplier compliance 
performance. The subsequent qualitative section builds on the quantitative findings and seeks to explain the black box: through which mechanisms buyers regulate supplier compliance.

\section{QUANTITATIVE ANALYSIS}

The quantitative section of this paper draws on the wealth of information collected by ILO BFC. ILO monitors conduct un-announced visits of all exporting garment factories every 6 to 8 months. As monitoring covers the entire population of exporting factories in Cambodia (approximately 300), there is no problem associated with sampling. While the ILO has been monitoring factories since 2001, monitoring and firm characteristic data have been systematically stored only since 2006. Accordingly, the data used for this study cover the period from January 2006 to December 2008 for 344 factories. During this period, ILO monitors visited factories 4 times on average. The data have been pooled to make a panel dataset of 1230 observations.

\section{Dependent Variable}

ILO monitors assess over 300 checklist items of labour standards, which are based on the Cambodian labour law and the international labour standards. The monitored standards have been agreed by a tri-partite governing body, comprising of the Cambodian government, employers, and unions in the garment industry. These standards are grouped into the following categories: contracts, wages, hours, leave, welfare, occupational safety and health $(\mathrm{OSH})$, labour relations, and fundamental rights. ${ }^{3}$

As for monitoring procedures, un-announced visits span an entire day or longer for larger establishments. The process includes on-site inspection, meetings with human resource 
managers, union leaders, and shop stewards as well as off-site interviews with workers. Copies of pay slips and hour records are collected for verification. ILO monitors assess each checklist item and determine whether a factory complies with a specified standard. When the factory is deemed out of compliance with a certain item, monitors make a standardised suggestion for improvement. Therefore, the presence of a suggestion is equivalent to noncompliance and the absence of a suggestion, compliance. In general, fewer suggestions or non-compliance items indicate better working conditions. ${ }^{4}$

The average compliance level during the period between 2006 and 2008 is 90 percent, where a score of 100 indicates full compliance. This suggests a very high level of overall compliance in Cambodia's garment industry during this period. Nonetheless, there is large variation in compliance performance, ranging from near-full compliance to over 100 noncompliance items. Figure 1 shows the frequency distribution of the number of noncompliance items in the sample. This quantitative section seeks to explain this variation: why do some factories have better labour compliance levels than other factories? The dependent variable, therefore, is the number of non-compliance items found in each monitoring visit.

\section{Independent Variables}

The independent variables are the presence and number of reputation-conscious buyers. This concept is operationalised by buyer membership of multi-stakeholder initiatives (MSI). Since reputation-conscious buyers tend to participate in MSI to show their commitment to better working conditions and safeguard their reputation, it is a reasonable proxy. Following O'Rourke (2006: 899), this paper defines MSI in labour regulation as a scheme that involves various stakeholders in negotiating labour standards, monitoring compliance with these standards, and establishing mechanisms to encourage firms to comply with these standards. 
While MSI can take various forms from certification of production facilities to collaboration of buyers, this paper concentrates on buyer-oriented schemes given our interest in the role of reputation-conscious buyers.

This paper considers three MSI: Better Factories Cambodia (BFC), the Fair Labor Association (FLA), and the Ethical Trading Initiative (ETI). BFC embodies an MSI approach given its tripartite governance structure. Buyers participating in BFC (hereafter BFC buyers) pay moderate fees to access to ILO monitoring reports. Currently, nearly 20 international buyers participate in BFC, most of which are brands and well-known retailers. The FLA, an American initiative, is the oldest and the best known brand-oriented MSI in labour regulation. It emphasises transparency, disclosure, and certification (Hughes et al., 2007). Member companies are required to implement the FLA CoC, submit to un-announced monitoring, and to commit to remediation and public reporting. Currently, 26 companies are participating, most of which are well-known apparel and sportswear brands. The ETI, a UK scheme, is geared toward collaboration and learning rather than monitoring and enforcement (Ibid.). The ETI encourages its member companies to implement its base code in their supply chains and require them to submit annual progress report on their code implementation. Currently, 50 companies are participating, most of which are European brands and retailers.

It is important to note the key differences between BFC and the other two MSI, the FLA and the ETI. First, BFC does not certify buyers and does not require buyers to implement certain codes or monitoring/reporting procedures. Second, buyers can fully rely on ILO monitoring and replace their own (or third-party) audits if they choose to, given the ILO's industry-wide monitoring. Third, while membership of the FLA and the ETI involves expensive fees, BFC 
only asks buyers to pay very reasonable fees to access to monitoring reports. Overall, BFC is more economical and less burdensome than the FLA and the ETI.

This paper operationalises the degree of reputation consciousness by dividing buyers into three groups: buyers that participate in BFC and the FLA or the ETI (hereafter MSI buyers); buyers that participate in BFC but not in the FLA or the ETI (hereafter BFC-only buyers); and buyers that participate in none of the MSI mentioned. The degree of reputation consciousness is considered high for MSI buyers, given the extra burden involved. Indeed, all the MSI buyers in the sample are branded buyers that have experienced negative publicity. BFC-only buyers are considered less reputation-conscious than the first group. These buyers are mostly large and well-known retailers. The third category of buyers that participates in none of the MSI is mostly smaller generic retailers that consumers hardly hear of and thus least reputation-conscious.

Table 1 shows the summary statistics of variables. BFC-only buyers are present in 31 percent of the factories in the sample. The number of BFC-only buyers sourcing from a factory ranges from 0 to 4 . As for MSI buyers, 27 percent of the factories in the sample produce for at least one MSI buyer, participating in either the FLA or the ETI in addition to BFC. ${ }^{5}$ This leaves 42 percent of factories that produce for buyers that join none of the MSI. There appears to be a significant negative association between the number of more or less reputation-conscious buyers in a factory and non-compliance (Figure 2 shows the number of all BFC buyers, which is a combination of BFC-only and MSI buyers).

\section{Control Variables}


However, buyer variables are unlikely to be the only factors that affect the factory-level compliance performance. Various establishment-level characteristics are clearly related to working conditions, and thus need to be controlled for. First of all, the size of the establishment, as measured by number of employees, can affect the level of compliance. Larger factories have made larger investment, raising their opportunity costs of exit, which, in turn, justifies larger investment to comply with labour standards. In particular, when investment involves large fixed costs, a minimum efficiency scale may be needed. Moreover, given that size increases employee alienation and supervisory costs, larger establishments are more likely to see the benefit of respecting labour standards to raise self-motivation and to minimise the source of disputes and monitoring cost (Bryson et al., 2007). For all these reasons, larger establishments are more likely to be associated with better compliance. The natural logarithm of total number of employees measures the size of the establishment.

Second, the age of the establishment is likely to influence the level of compliance. Factory management may learn the benefit of compliance or the cost of non-compliance over time (age). ${ }^{6}$ On the other hand, the age of the establishment may impose physical constraints: older establishments tend to have older facilities and limited space, making it more difficult and costly to comply with certain standards concerning welfare as well as safety and health (Bryson et al., 2007). Given the lack of precise data on this variable, total number of visits by ILO monitors since 2001 is used as a proxy, ranging from 1 to 9.

Third, unions are likely to affect the factory's working conditions. That unions raise wages and improve worker benefits has been widely researched and acknowledged (Freeman and Medoff, 1984). Moreover, unionised establishments are found to violate fewer safety and health standards (Weil, 2001). In Cambodia, labour unions have grown both in number and 
in power since the revision of the labour code in 1997. In the sample, the number of unions ranges from 0 to 6 , with a mean of 1.3 unions in a factory. Disputes and strikes are a major threat for employers in a time-sensitive business like garment. Since unions are likely to raise the cost of non-compliance through possible disputes and strikes, employers of unionised establishments and especially those with a larger number of unions are more likely to comply with labour standards.

Fourth, the factory's ownership may help explain the variation in labour standard compliance. Foreign-owned firms tend to provide better pay to workers than their domestic counterparts, given the MNEs' advanced technological know-how and management systems (OECD, 2008). In Cambodia, over 90 percent of exporting garment factories is foreign owned while 61 percent is owned by investors from Taiwan, Hong Kong, and China. ${ }^{7}$ This study will assess whether a minority of factories under the Western and Cambodian ownership is different from the rest in terms of compliance level.

\section{Model Specifications}

This section tests whether the degree and number of reputation-conscious buyers have a significant effect on supplier labour standard non-compliance. In addition to the variables discussed above, year control dummies for 2006 and 2007 are added to form the following model:

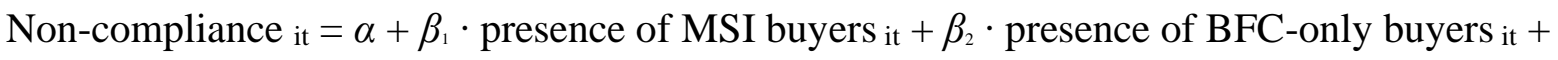

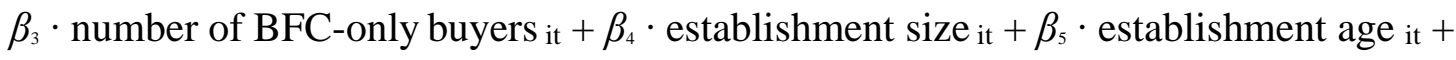
$\beta_{6} \cdot$ union presence $_{\text {it }}+\beta_{7} \cdot$ number of unions it $+\beta_{8} \cdot$ domestic ownership $_{\text {it }}+\beta_{9} \cdot$ western ownership $_{\text {it }}+\beta_{10} \cdot$ year $2006_{\text {it }}+\beta_{11} \cdot$ year 2007 it $+\varepsilon_{\text {it }}$ 
Three types of specifications have been estimated: an Ordinary Least Squares (OLS) estimate using the raw number of non-compliance items (raw OLS), an OLS estimate using the natural logarithm of non-compliance items (semi-log OLS), and a between effects estimate using the natural logarithm of non-compliance items (semi-log between effects).

Considering the nature of the data (i.e. panel data with a large number of cases and a small number of time periods) and the question this paper seeks to answer (i.e. why do some factories have better compliance levels than others?), between effects model is considered more appropriate. The between effects model is used as a check to the semi-log OLS, our preferred model given its intuitive results, efficiency, and larger degrees of freedom.

\section{Results}

All three models show a significant negative association between reputation-conscious buyer variables and non-compliance (Table 2). In other words, non-compliance is reduced when a factory is producing for reputation-conscious buyers. Specifically, the presence of MSI buyers is consistently significant at the 0.001 level. In terms of coefficients, the presence of MSI buyers reduces non-compliance by 35 percent. In the raw OLS model, this translates to a reduction in non-compliance items by 13 items. This result supports the first hypothesis that factories producing for at least one particularly reputation-conscious buyer have better compliance performance than other factories.

As for BFC-only buyers, the presence of BFC-only buyers is not consistently significant although the number of BFC-only buyers is highly significant across all models. An additional BFC-only buyer in a factory reduces non-compliance by 11.2 percent, which is 
equivalent to 2.8 items in the raw OLS model. This indicates that a less reputation-conscious buyer alone does not induce a marked improvement in supplier compliance, but when more of them are sourcing from the same factory, they create a critical mass of pressure to bring about better working conditions. This result supports the second hypothesis about the number of buyers.

Among control variables, the size of the establishment is statistically significant across all three models. Larger factories enjoy economies of scale and tend to have more resources and sophisticated management systems. The age of the establishment is positively associated with non-compliance, suggesting that newer purpose-built factories have better compliance levels. Union presence is not found to be statistically associated with compliance. Domestic ownership is highly significant and it increases non-compliance while Western ownership reduces non-compliance. This result is consistent with the theory of foreign wage premium as Cambodian-owned factories tend to lack managerial know-how and financial means while the opposite is the case for Western-owned factories. Year dummy controls show that compliance performance has significantly improved in 2008 compared to 2006 and 2007.

\section{QUALITATIVE ANALYSIS}

While the above quantitative analysis has confirmed the statistically significant relationship between reputation-conscious buyers and supplier compliance, data constraints prevent us from delving into the mechanisms through which buyers regulate their supplier compliance. The strength of case study research lies in in-depth analysis of few cases to shed light on causal processes. While various types of case studies exist, this section represents a "pathway 
case," which seeks to demonstrate causal mechanisms building on quantitative analysis (Gerring, 2007: 122).

This section is based on the author's fieldwork conducted in the summers of 2007 and 2008 in Phnom Penh, Cambodia. The author conducted 61 semi-structured interviews with factory managers, buyer representatives, industry experts, union federation leaders, labour activists, government officials, and international donors. All interviewees remain anonymous as the content includes sensitive issues. While a number of factors influence working conditions, reputation-conscious buyers were frequently mentioned as a key player. Specifically, these buyers steer suppliers both reactively and proactively while some suppliers make proactive efforts to improve working conditions despite constraints imposed by purchasing practices.

\section{Pressure-driven Enforcement}

Buyers can make a significant impact at the factory level particularly when transnational advocacy networks are mobilised to pressure buyers. Specifically, activists engage in what Keck and Sikkink (1998) call "accountability politics," where transnational advocacy networks act as a source of countervailing power, hold MNEs to their $\mathrm{CoC}$, and pressure them to adopt more stringent standards (Rodriguez-Garavito, 2005). Important networks for anti-sweatshop campaigns are international trade union federations, student organisations, and other pro-labour NGOs. Such transnational linkages have proved helpful in improving working conditions in a few garment factories in Cambodia as demonstrated by the following two examples.

A union federation leader cited one major case that mobilised a transnational solidarity network to address anti-union discrimination. ${ }^{9}$ River Rich factory dismissed 30 union leaders 
and members after they organised an election to form an independent union in October 2006. Strikes calling for the reinstatement of the union members faced the riot police. As the union belonged to the federation, CCAWDU, which was affiliated with the International Textile Garment Leather Workers' Federation (ITGLWF), they asked for assistance. Lack of cooperation from the management led the ITGLWF to pressure the factory's major buyers, Inditex and H\&M for action. In June 2007, the senior representatives from the ITGLWF, Inditex, H\&M, and CCAWDU had intensive discussions with the factory's top management, which resulted in a historic agreement that went beyond the reinstatement of fired workers. ${ }^{10}$ Since then, River Rich has been enjoying stable and cooperative industrial relations, thanks to this transnational linkage between the union, the international union federation, and the buyers. ${ }^{11}$ Since the union has a close connection with the key buyers, the factory management is aware that the union may contact the buyers if any issues arise.

Another illustrative case involves the Worker Rights Consortium (WRC), Adidas, and PCCS garment factory. The WRC is a US NGO that investigates worker complaints and promotes information disclosure in factories producing University branded products. In 2006, the WRC was contacted by workers to investigate the misuse of short-term contracts in the factory. ${ }^{12}$ The Cambodian labour law stipulates that fixed duration contracts should be used for temporary positions and that they cannot exceed 2 years. At the factory, some workers were hired under the contract of fixed duration for 2 to 3 months, after which time they were instructed to take a week-off and then come back to work under new fixed term contracts. This practice deprives workers of their right to seniority bonus, maternity and annual leave among other benefits while it undermines employment security from inappropriate dismissal. At the time of WRC investigation in March 2006, around 1000 employees, about 25 percent of workforce, were under the fixed term contracts. ${ }^{13}$ 
As the initial discussions between the WRC and the management produced no effects, the WRC pressured Adidas, the factory's major buyer, to take action. With the intervention of Adidas, the discussions started to take on a different tone. Adidas issued a warning to the management that unless the factory converted all fixed-term contracts to non-determined ones in one month, it would cancel its orders. ${ }^{14}$ Only after this key intervention by Adidas, the management started to change and finally agreed to make drastic changes. ${ }^{15}$ The factory agreed to convert the majority of fixed-term contracts into non-determined ones, and this has been respected since.

Despite these successful examples, this transnational tactic of using buyer leverage to bring about positive changes at the factory level has its limitations. The WRC investigator acknowledges that reputation-conscious brands are more prone to pressures and therefore more cooperative, but other buyers care less. While this transnational strategy may work for major issues, it cannot deal with smaller day-to-day issues. A union federation leader involved in the River Rich case concurs that it is time-consuming and costly to pursue this tactic. ${ }^{16}$ Moreover, those who can exploit transnational linkages are limited to well-connected and English speaking union federations. ${ }^{17}$ All in all, mobilisation of transnational networks may bring about positive changes in some factories that produce for reputation-conscious buyers, but it is unlikely to address various day-to-day issues in the majority of factories.

Even if such transnational networks cannot be mobilised every time, however, the possibility of such an alliance has changed dynamics. Establishment-level unions have also come to see buyers as a source of leverage and an authority that can enforce the labour law and improve worker welfare. Indeed, more than a few factory managers complain that unions threaten that 
they will call buyers if management does not cooperate. In fact, not only unions but also government officials sometimes turn to buyers for help. Since government safety and health inspectors lack enforcement power unlike labour inspectors, they contact buyers to ask for remedial action when serious safety and health issues are found in garment factories producing for famous brands. ${ }^{18}$

\section{Buyer-driven Enforcement}

Through repetitive interactions with transnational activist networks over the past decade, some buyers have come to take a proactive approach to regulating working conditions in their suppliers. Bartley (2005) discusses the dynamic interplay between companies and pressure groups, which gradually changes the terms of debate and regulated terrain. Indeed, some buyers have become proactive and increasingly involved in remediation at the factory-level.

Major brands sourcing from Cambodia, the Gap and H\&M have local representatives who deal specifically with compliance issues. The Gap takes a pre-emptive approach and tries to stay well-informed of situations in their supplier factories so that they can intervene at an earlier stage. "We don't want a bad surprise. We don't want to learn about a problem in our supplier factory in some newspaper. Rather, we try to intervene before the problem gets bigger." ${ }^{19}$ The Gap's local representative has extensive contacts with union leaders and helps resolve issues on a daily basis. In fact, other buyers without local staff sometimes even ask them to intervene in their supplier factories when problems arise. The Gap is also heavily involved in dispute resolution. They pressure their suppliers to implement both binding and non-binding awards of the Arbitration Council, a tripartite entity set up by the ILO to deal with collective disputes. They enjoy such leverage vis-à-vis their suppliers partly because 
they tend to be the major buyer for their suppliers, accounting for up to 70 percent of production in some of factories.

The policy of H\&M vis-à-vis their supplier compliance is "transparency, cooperation, and openness." ${ }^{20}$ Locally-based compliance staff visit their suppliers 3 to 4 times a year for two different purposes. First, there are visits based on a remediation cycle of 18 to 24 months, consisting of an un-announced visit and three follow-up visits. Then, there are "ordinary visits," whose purpose is to engage in continuous dialogue and share best practices. This way, H\&M compliance staff try to foster an open relationship with suppliers, which helps to keep them informed of the situation and to contribute to suppliers' continuous improvement. H\&M local compliance staff also work closely with unions. When problems arise, they try to play a neutral mediator role between factory management and unions. When collective disputes are settled at the Arbitration Council, H\&M enforces binding awards and sometimes also nonbinding awards, depending on the nature and context of cases.

Nonetheless, not all buyers are so proactive and willing to invest their time and efforts to understand and solve problems in supplier factories. Multiple interviews have confirmed the difference in buyer approaches. Well-known brands, in particular those with local representatives, are more well-informed of the local situation and readily available to help solve problems on the factory floor. Moreover, these buyers tend to have more direct contact and established relationships with supplier factories, increasing their leverage. In contrast, other lesser known retailers were never mentioned as helpful partners. These generic retailers tend to use sourcing agents, and thus their relationships with supplier factories are much more distant and mediated, diluting their leverage. 


\section{Supplier Efforts and Purchasing Practices}

Not only buyers but also some factories are taking a proactive approach. Since most buyers require factories to comply with their $\mathrm{CoC}$ and the national law before placing orders, factories learn about the required standards in advance and try to meet them, and some even try to go beyond the minimum standards. One factory manager mentioned that their current buyers do not have issues with their compliance performance, but the factory makes continuous and proactive efforts to improve working conditions to attract more buyers. ${ }^{21}$ Given the fickle nature of the industry and the slowing global economy, factories are keen to diversify risks by producing for different buyers from the US and Europe.

Different buyers have different standards. One factory manager remarks "Nike is much stricter about everything." 22 Since buyers who require higher standards tend to be famous brands that give higher profit margins, factories trying to attract them need to improve compliance and sometimes go beyond the national labour law. "Buyer $\mathrm{CoC}$ often go beyond the legal requirements, so if we comply with $\mathrm{CoC}$, naturally, we go beyond legal compliance." ${ }^{23}$ Nonetheless, many factory managers complain that compliance with buyer $\mathrm{CoC}$ is simply a minimum requirement to get orders, and better compliance does not bring more orders. "No compliance, no orders. But better compliance is not rewarded. It just gets you at the start line."24

In fact, purchasing practices of buyers-including reputation-conscious ones-sometimes contradict with the goal of improving working conditions (Oxfam, 2004; CCC, 2009). A factory manager explains that significant fluctuations in orders make it difficult to keep all of their workers during the low seasons. ${ }^{25}$ The garment industry is strongly marked by seasonality. In low seasons, some workers remain idle although the factory has to keep 
paying their wages. While some buyers require suppliers to hire workers on permanent contracts, they do not share the burden of extra labour costs. Consequently, factory management is sandwiched by buyers' increasing demands and falling profits.

In recent years, intense competition and rising prices have squeezed garment producers' profits. One factory manager laments as follows: "Three years ago, the price of pant was $\$ 10$ a piece and the cost to produce was $\$ 6$ a piece. Now, the price stays the same and the cost has gone up to $\$ 8-9$ a piece. Buyers don't increase the price because they can go elsewhere if they want to. It's a buyers' market." 26 While brands are also pushing for lower prices, generic retailers are much more aggressive. One factory manager says he does not consider producing for retailers such as Wal-Mart because margins are too narrow to make profits. ${ }^{27}$

\section{Summary}

All in all, the gap in compliance performance appears to stem from reputation-conscious buyers' tendency to rigorously regulate supplier compliance performance through pre-order selection and post-order enforcement, both reactively and proactively. Buyers act reactively in cases where transnational advocacy networks are mobilised to pressure them and demand remedial action in supplier factories. Through repetitive interactions, however, some reputation-conscious buyers have learned to be more proactive in addressing compliance issues in their supplier factories. On the other hand, some factories have come to see better compliance as a way of attracting reputation-conscious buyers and actively try to improve working conditions. Nonetheless, better compliance is not rewarded by buyers and some purchasing practices conflict with the goal of improving working conditions. 
While engaged buyers tend to be famous brands, this may change as labour practices of largescale retailers such as Wal-Mart increasingly come under scrutiny (CCC, 2009). If this trend continues and intensifies, these giant retailers may eventually follow reputation-conscious brands and learn to actively engage with suppliers. The quantitative findings indicate that a larger number of less reputation-conscious buyers sourcing from the same factory are associated with better compliance performance. This suggests potential for a critical mass of less reputation-conscious buyers to induce better compliance in supplier factories.

\section{CONCLUSION}

The role of business in development continues to expand. In particular, business has been taking over some of the regulatory roles traditionally assumed by government. The globalised garment industry provides a striking example of how MNEs have come to regulate labour conditions in their supply chains in developing countries. Despite the scale and significance of this phenomenon, systematic investigation of the impact of buyers on supplier working conditions has been scarce. In particular, the question of whether buyer-driven regulation creates only pockets of best practices or leads to overall improvement remains largely unanswered.

Based on the unique firm-level data and field interviews in Cambodia's garment sector, this paper has sought to examine whether and how different types and number of buyers affect labour standard compliance of suppliers. The quantitative findings clearly show that factories supplying for at least one particularly reputation-conscious buyer tend to have a better compliance level than other factories. Moreover, as the number of less reputation-conscious buyers sourcing from the same factory increases, so does the compliance level. The 
qualitative section has demonstrated that reputation-conscious buyers enforce labour standards both reactively and proactively, but buyers willing to engage with stakeholders are often branded buyers under public scrutiny.

The findings point to both the opportunities and limits of private sector-driven regulation in the developing world. Contrary to the criticism that global brands are exacerbating a "race to the bottom" and that private regulation is ineffective, this paper has shown that reputationconscious buyers exercise an important regulatory role. Nonetheless, the study has revealed a compliance gap among factories supplying for buyers with different degrees of reputation consciousness. In fact, the gap is not inherently harmful if some factories achieve better standards and the other factories follow in their footsteps. In Cambodia's exporting garment sector, the general compliance level has significantly improved over the past decade and "sweatshop" conditions are virtually non-existent. This result owes much to the ILO, which has constantly monitored all exporting garment factories, helped resolve collective disputes by setting up a tripartite Arbitration Council, and provided training and raised worker awareness about labour rights.

All these factors, however, make the Cambodian case more unique than universal, which is one of the limitations of this study. The Cambodian case does not reflect purely buyer-driven regulation, but rather a combination of public and private regulatory mechanisms. This implies that working conditions in purely buyer-regulated supply chains are likely to be worse. Another limitation of this research is its exclusive focus on monitored factories although working conditions in subcontractors are reportedly worse. 
Nevertheless, important lessons can be learned from examining the Cambodian case. To spread the benefits of better working conditions more widely, each actor has an important role to play. First, activists and the media need to expand the scope of their attention and target not only branded buyers but also non-branded buyers so that the latter start changing the cost-benefit calculation and become more engaged with suppliers. Second, buyers need to reward suppliers for better compliance and address purchasing practices that conflict with better working conditions. Moreover, buyers should join forces and better coordinate themselves to use the leverage of critical mass. Lastly, better coordination and enforcement requires capable government and effective international organisations, which are the ultimate source of sustainable progress in working conditions.

It is increasingly acknowledged that public policy plays a critical role in supporting private regulation and that private regulation has inherent limits (Vogel, 2005; Graham and Woods, 2006; Kuruvilla and Verma, 2006; Seidman, 2008). For instance, while the Cambodian case is often cited as a model scheme, it originates from a trade agreement, mandated by the Cambodian government, largely financed by international donors, and operated by the ILO. Moreover, sustainable progress in working conditions beyond the exporting garment sector inevitably requires government involvement. Without effective public policy intervention, therefore, private regulation is unlikely to bring about sustainable and across-the-board progress. Even as the role of business in regulation continues to grow, governments and international organisations have important roles to play by providing the right framework and incentives for the private sector. 


\section{NOTES}

${ }^{1}$ For more information about the ILO monitoring programme, consult their website: http://www.betterfactories.org/

${ }^{2}$ The ILO monitoring programme has been mostly financed by international donors, namely the US Department of Labor (USDOL), USAID, the Agence Française de Développement (AFD), as well as by the Cambodian Government, the Garment Manufacturers Association of Cambodia (GMAC) and international buyers. As the programme seeks to be self-sustaining beyond 2010, the financing scheme is set to change.

${ }^{3}$ The category of labour relations is not included in the analysis because the problem of clustering distorts true compliance performance.

${ }^{4}$ Recently, it is increasingly acknowledged that compliance is a limited measure of actual working conditions given the prevalence of audit fraud such as double-book keeping (Barrientos and Smith, 2007). Moreover, monitoring fundamental rights, including freedom of association, discrimination, child labour, remains a difficult task. Despite these challenges, ILO monitoring results in Cambodia's garment sector are the most comprehensive and reliable industry-wide data available on the general state of working conditions in garment factories.

${ }^{5}$ The number of MSI buyers sourcing from the same factory is small, and thus this variable is highly correlated with the presence variable (>0.89), which is why it is dropped from regression analysis.

${ }^{6}$ Factory management can also learn from training. The ILO provides various training on labour standards and human resource management to factories on a voluntary basis. While it is beyond the scope of this paper, this avenue may be explored in future work.

${ }^{7}$ Figures from Garment Manufacturers' Association of Cambodia (GMAC).

${ }^{8}$ Although the types of unions may have made the difference for the outcome, data limitation precludes further investigation. ILO (2006) finds that independent unions are more helpful for workers than government-supported unions.

${ }^{9}$ Interview with union federation leader, CCAWDU. 10 September, 2007.

${ }^{10}$ The agreement is available from the website of the ITGLWF: http://www.itglwf.org/DisplayDocument.aspx?idarticle=15317\&langue=2

${ }^{11}$ Interview with training expert. 12 September, 2008.

${ }^{12}$ Interview with WRC investigator. 4 September, 2007.

${ }^{13}$ The WRC investigation report on this case is available from their website: http://www.workersrights.org/Freports/Update_Dec2006.asp\#PCCS

${ }^{14}$ Interview with general manager, PCCS Garment. 21 June, 2008. 
${ }^{15}$ Interview with WRC investigator. 4 September, 2007.

${ }^{16}$ Interview with union federation leader, CCAWDU. 10 ${ }^{\text {th }}$ September, 2007.

${ }^{17}$ Interview with union federation leader, FTUWKC. 26 September, 2007.

${ }^{18}$ Interview with official, Department of Occupational Safety and Health. 21 September, 2007.

${ }^{19}$ Interview with the Gap representative. 24 June, 2008.

${ }^{20}$ Interview with H\&M representative. 16 October, 2008.

${ }^{21}$ Interview with factory manager. 11 September, 2008.

${ }^{22}$ Interview with factory manager. 16 September, 2008

${ }^{23}$ Ibid.

${ }^{24}$ Interview with factory manager. 21 June, 2008.

${ }^{25}$ Ibid.

${ }^{26}$ Interview with factory manager. 14 October, 2008.

${ }^{27}$ Interview with factory manager. 21 June, 2008. 


\section{REFERENCES}

Ashenfelter, O. and R. S. Smith. (1979) Compliance with the minimum wage law. Journal of Political Economy, 87(2): 333-350.

Barrientos, S., C. Dolan, and A. Tallontire. (2003) A gendered value chain approach to codes of conduct in African horticulture. World Development 31(9): 1511-1526.

Barrientos, S. and S. Smith. (2007) Do workers benefit from ethical trade? Assessing codes of labour practice in global production systems. Third World Quarterly 28 (4): 713729.

Bartley, T. (2005) Corporate Accountability and the Privatization of Labour Standards: Struggles Over Codes of Conduct in the Apparel Industry. In: H. Prechel (ed.), Politics and the Corporation. Texas: Elsevier, pp. 211-244.

Becker, G. (1983) A theory of competition among pressures groups for political influence. Quarterly Journal of Economics, 98(3): 371-400.

Brady, H., E. and D. Collier (eds.) (2004) Rethinking Social Inquiry: Diverse Tools, Shared Standards. Oxford: Rowman \& Littlefield

Bryson, A. R. Gomez, T. Kretschmer, and P.Willman. (2007) The diffusion of workplace voice and high-commitment management practices in Britain, 1984-1998. Industrial and Corporate Change 16(3): 395-426.

CCC (Clean Clothes Campaign). (2009) Cashing In: Giant Retailers, Purchasing Practices, and Working Conditions in the Garment Industry. Amsterdam: CCC.

Conroy, M. E. (2007) Branded: How the Certification Revolution is Transforming Global Corporations. Gabriola Island, BC: New Society Publishers.

Elliott, K. A. and R. B. Freeman. (2003) Can Labor Standards Improve Under Globalization? Washington, DC: Institute for International Economics

Esbanshade, J. (2004) Monitoring Sweatshops: Workers, Consumers and the Global Apparel Industry. Philadelphia: Temple University.

Freeman, R. B. and J. L. Medoff. (1984) What do Unions do? New York: Basic Books

Frenkel, S. J. (2001) Globalization, athletic footwear commodity chains and employment relations in China. Organization Studies 22(4): 531-562.

Frenkel, S. J. and D. Scott. (2002) Compliance, collaboration, and codes of labour practice: the ADIDAS connection. California Management Review 45(1): 29-49.

Gereffi, G., J. Humphrey, T. Sturgeon. (2005) The governance of global value chains. Review of International Political Economy 12(1): 78-104. 
Gerring, J. (2007) Case Study Research: Principles and Practices. Cambridge: Cambridge University Press.

Graham, D. and N. Woods. (2006) Making corporate self-regulation effective in developing countries. World Development 34(5): 868-83.

Hughes, A., M. Buttle, and N. Wrigley. (2007) Organisational geographies of corporate responsibility: A UK-US comparison of retailers' ethical trading initiatives. Journal of Economic Geography 7: 491-513.

ILO (International Labour Organization). (2006) Women and Work in the Garment Industry. Phnom Penh: ILO

Jenkins, R., R. Pearson, and G. Seyfang. (2002) Corporate Responsibility and Labor Rights: Codes of Conduct in the Global Economy. London: Earthscan.

Jiang, B. (2009) Implementing supplier codes of conduct in global supply chains: Process explanations from theoretic and empirical perspectives. Journal of Business Ethics 85: 77-92.

Keck, M. and K. Sikkink. (1998) Activists Beyond Borders: Transnational Advocacy Networks in International Politics. Ithaca, NY: Cornell University Press.

Kolben, K. (2004) Trade, monitoring, and the ILO: Working to improve conditions in Cambodia's garment factories." New Haven, CT: Yale Human Rights \& Development Journal 7: 79-107.

Kuruvilla, S. and A. Verma. (2006) International labor standards, soft regulation, and national government roles. Journal of Industrial Relations, 48(1): 41-58.

Locke, R. M., F. Qin, and A. Brause. (2007) Does monitoring improve labor standards? Lessons from Nike. Industrial and Labor Relations Review 61(1): 3-31.

Locke, R. M. and M. Romis. (2006) Beyond corporate codes of conduct: Work organization and labour standards in two Mexican garment factories. Corporate Social Responsibility Initiative Working Paper no. 26. Cambridge, MA: John F. Kennedy School of Government, Harvard University.

Nadvi, K. and W. Frank. (2004) Making Sense of Global Standards. In: H. Schmitz (eds), Local Enterprises in the Global Economy: Issues of Governance and Upgrading. Northhampton, MA: Edward Elgar.

OECD (Organisation for Economic Co-operation and Development). (2008) OECD Employment Outlook. Paris: OECD.

O'Rourke, D. (2006) Multi-stakeholder regulation: Privatizing or socializing global labour standards? World Development 34(5): 899-918.

Oxfam. (2004) Trading Away Our Rights: Women Workers in Global Supply Chains. Oxford: Oxfam. 
Polaski, S. (2006) Combining global and local forces: The case of labor rights in Cambodia. World Development 34(5): 919-932.

Rodriguez-Garavito, C. (2005) Global governance and labour rights: Codes of conduct and anti-sweatshop struggles in global apparel factories in Mexico and Guatemala. Politics and Society 33: 203-233.

Seidman, G. (2008) Transnational labour campaigns: Can the logic of the market be turned against itself? Development and Change 39(6): 991-1003.

Stigler, G. (1971) The theory of economic regulation. Bell Journal of Economics and Management Science 2: 3-21.

Viscusi, W. K. (1979) The impact of occupational safety and health regulation. The Bell Journal of Economics 10: 117-140.

Vogel, D. (2005) The Market for Virtue: The Potential and Limits of Corporate Social Responsibility. Washington, D.C.: Brookings Institution Press.

Weil, D. (2001) Assessing OSHA performance: New evidence from the construction industry. Journal of Policy Analysis and Management 20(4): 651-674.

Weil, D. (2005) Public enforcement/private monitoring: Evaluating a new approach to regulating the minimum wage. Industrial and Labor Relations Journal 58(2): 238-257.

Weil, D. and C. Mallo. (2007) Regulating labour standards via supply chains: Combining public/private interventions to improve workplace compliance. British Journal of Industrial Relations 45(4): 791-814. 
FIGURE 1.

The frequency distribution of non-compliance items

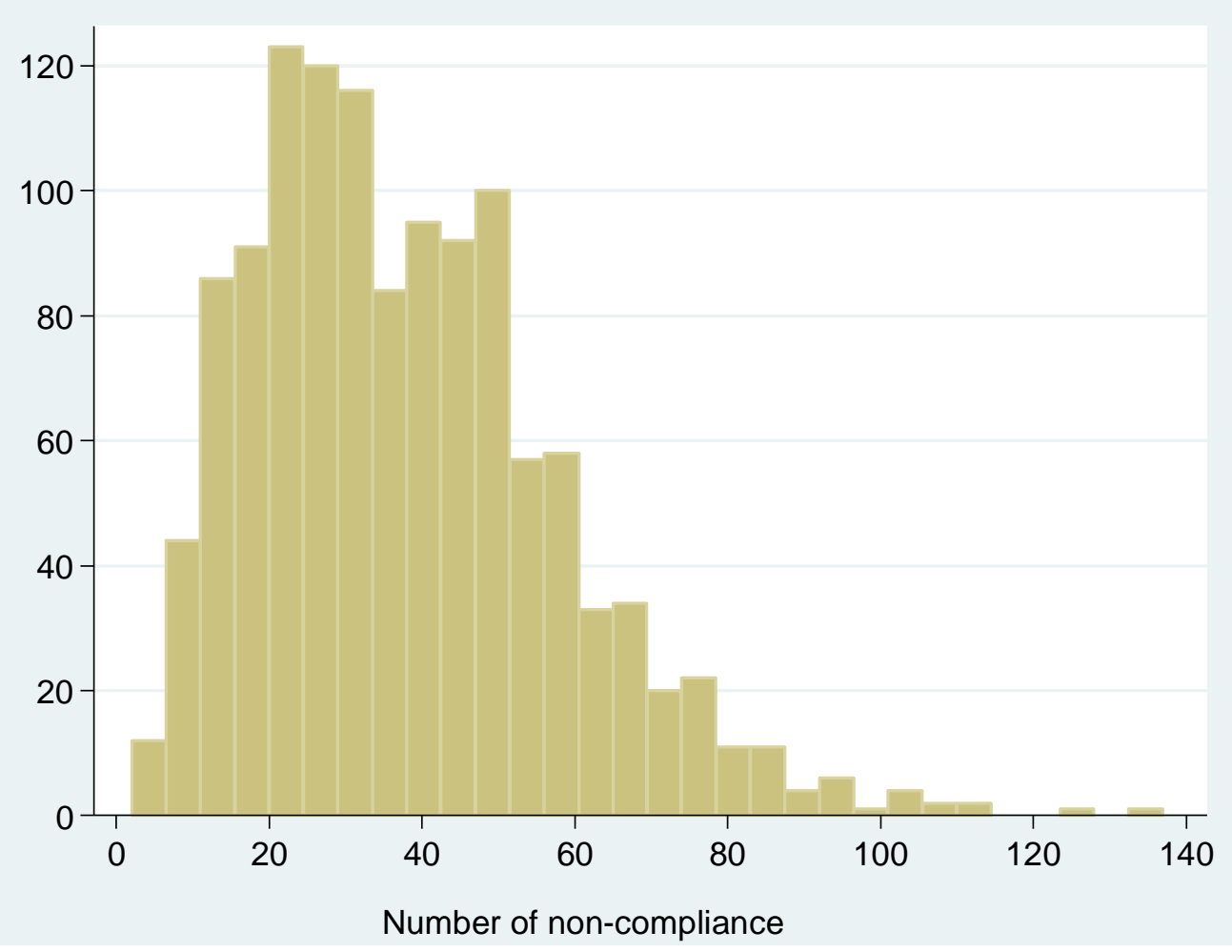


FIGURE 2.

Relationship between the number of BFC buyers in a factory and non-compliance items

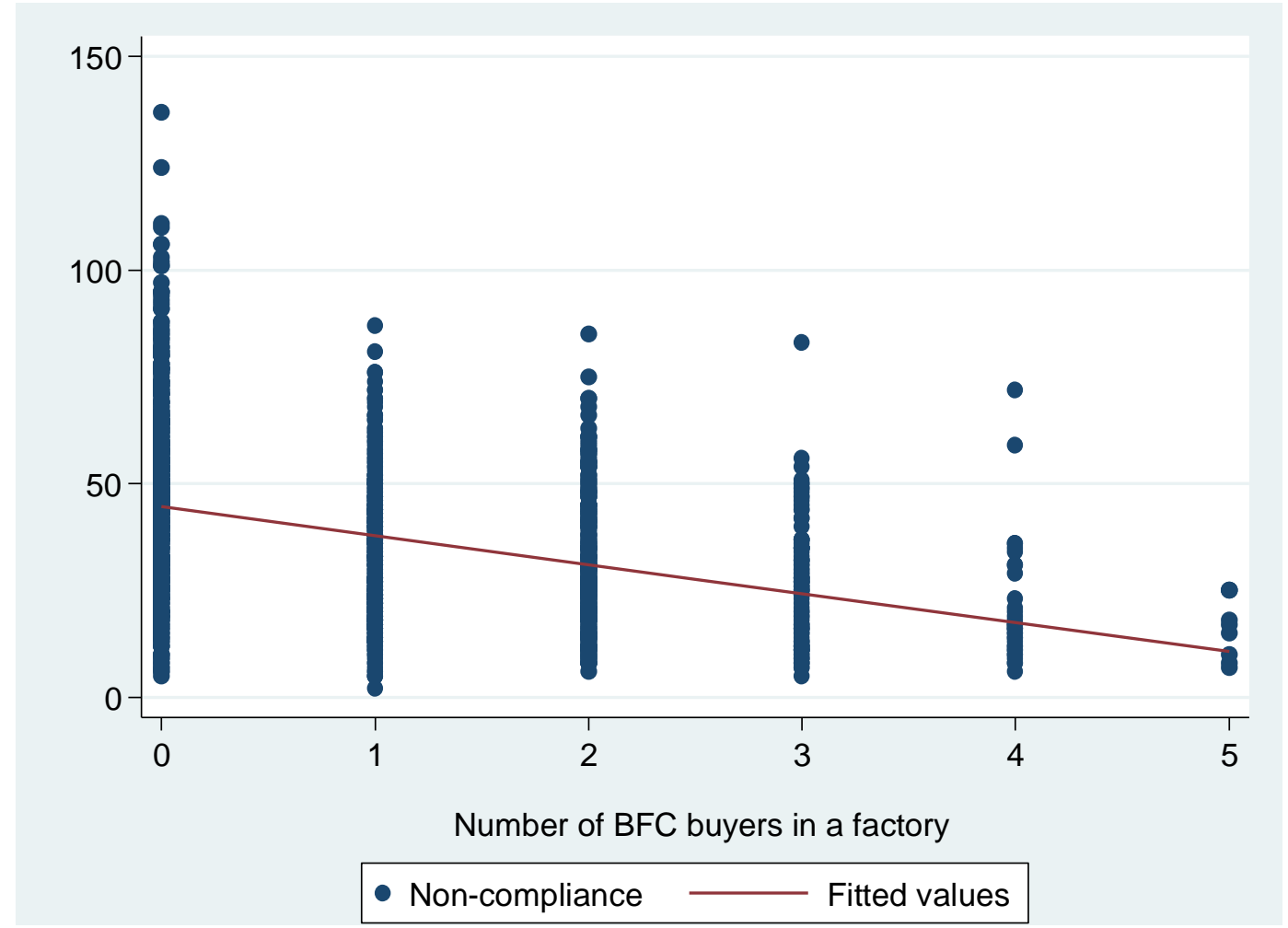

Notes: BFC buyers are those buyers participating in ILO Better Factories Cambodia (BFC). 
TABLE 1.

Descriptive statistics of variables

\begin{tabular}{lccccc}
\hline \multicolumn{1}{c}{ Variable } & Obs & Mean & S.D. & Min. & Max. \\
\hline Number of Non-compliance items & 1230 & 37.58 & 19.81 & 2 & 137 \\
Log of number of non-compliance items & 1230 & 3.47 & 0.59 & 0.69 & 4.92 \\
Presence of MSI buyers (1=yes, 0=no) & 1230 & 0.27 & 0.44 & 0 & 1 \\
Presence of BFC-only buyers (1=yes, 0=no) & 1230 & 0.31 & 0.46 & 0 & 1 \\
Number of BFC-only buyers & 1230 & 0.71 & 0.99 & 0 & 4 \\
$\begin{array}{l}\text { Establishment Size } \\
\text { (Log of total number of employees) }\end{array}$ & 1230 & 6.8 & 0.78 & 2.77 & 8.92 \\
$\begin{array}{l}\text { Establishment Age } \\
\text { (Total number of ILO monitor visits) }\end{array}$ & 1230 & 4.34 & 2.09 & 1 & 9 \\
Union Presence (1=yes, 0=no) & 1230 & 0.78 & 0.41 & 0 & 1 \\
Number of Unions & 1230 & 1.36 & 1.16 & 0 & 6 \\
Domestic Ownership (1=yes, 0=no) & 1229 & 0.05 & 0.23 & 0 & 1 \\
$\begin{array}{l}\text { Western Ownership (1=yes, 0=no) } \\
\text { (12) }\end{array}$ & 1221 & 0.06 & 0.24 & 0 & 1 \\
\hline
\end{tabular}

Note: "BFC-only buyers" are those buyers participating in ILO Better Factories Cambodia (BFC) but not in other major MSI, namely the Fair Labour Association (FLA) or the Ethical Trading Initiative (ETI). "MSI buyers" are those buyers participating in BFC as well as the FLA or the ETI. 
TABLE 2.

Regression results of labour standard non-compliance on selected variables

(Jan 2006- Dec 2008)

\begin{tabular}{|c|c|c|c|}
\hline & \multicolumn{2}{|c|}{ OLS } & \multirow{2}{*}{$\frac{\text { Between Effects }}{\text { Ln (Non-Compliance) }}$} \\
\hline & Non-Compliance & Ln (Non-Compliance) & \\
\hline $\begin{array}{l}\text { Presence of MSI buyers } \\
(1=\text { yes, } 0=\text { no })\end{array}$ & $\begin{array}{l}-13.254 * * * * \\
(1.46)\end{array}$ & $\begin{array}{l}-0.346 * * * * \\
\quad(0.04)\end{array}$ & $\begin{array}{l}-0.451^{* * * * *} \\
\quad(0.08)\end{array}$ \\
\hline $\begin{array}{l}\text { Presence of BFC-only buyers } \\
(1=y e s, 0=\text { no) }\end{array}$ & $\begin{array}{l}-4.594 * * * \\
(1.56)\end{array}$ & $\begin{array}{l}-0.048 \\
(0.05)\end{array}$ & $\begin{array}{l}-0.024 \\
(0.10)\end{array}$ \\
\hline Number of BFC-only buyers & $\begin{array}{c}-2.769 * * * * * \\
(0.56)\end{array}$ & $\begin{array}{c}-0.112 * * * * \\
(0.02)\end{array}$ & $\begin{array}{c}-0.148 * * * * * \\
(0.05)\end{array}$ \\
\hline $\begin{array}{l}\text { Establishment Size } \\
\text { (Log of total number of employees) }\end{array}$ & $\begin{array}{l}-3.775 * * * * \\
(0.87)\end{array}$ & $\begin{array}{c}-0.127 * * * * \\
(0.02)\end{array}$ & $\begin{array}{l}-0.082 * \\
(0.04)\end{array}$ \\
\hline $\begin{array}{l}\text { Establishment Age } \\
\text { (Number of ILO monitor visits) }\end{array}$ & $\begin{array}{l}0.551^{* *} \\
(0.24)\end{array}$ & $\begin{array}{c}0.019^{* *} \\
(0.01)\end{array}$ & $\begin{array}{l}0.015 \\
(0.02)\end{array}$ \\
\hline $\begin{array}{l}\text { Union Presence } \\
(1=\text { yes, } 0=\text { no })\end{array}$ & $\begin{array}{l}0.718 \\
(1.44)\end{array}$ & $\begin{array}{l}0.026 \\
(0.04)\end{array}$ & $\begin{array}{l}-0.048 \\
(0.08)\end{array}$ \\
\hline Number of Unions & $\begin{array}{l}-0.590 \\
(0.45)\end{array}$ & $\begin{array}{l}-0.024 \\
(0.02)\end{array}$ & $\begin{array}{l}-0.010 \\
(0.03)\end{array}$ \\
\hline $\begin{array}{l}\text { Domestic Ownership } \\
(1=\text { yes, } 0=\text { no) }\end{array}$ & $\begin{array}{l}9.754 * * * * \\
\quad(2.79)\end{array}$ & $\begin{array}{l}0.190 * * * * \\
\quad(0.06)\end{array}$ & $\begin{array}{c}0.167 * \\
(0.10)\end{array}$ \\
\hline $\begin{array}{l}\text { Western Ownership } \\
(1=\text { yes, } 0=\text { no })\end{array}$ & $\begin{array}{l}-3.538^{*} \\
(1.82)\end{array}$ & $\begin{array}{l}-0.123^{*} \\
(0.07)\end{array}$ & $\begin{array}{l}-0.117 \\
(0.10)\end{array}$ \\
\hline $\begin{array}{l}\text { Year } 2006 \\
(1=\text { yes, } 0=\text { no })\end{array}$ & $\begin{array}{l}14.297 * * * * \\
(1.26)\end{array}$ & $\begin{array}{l}0.416 * * * * \\
\quad(0.04)\end{array}$ & $\begin{array}{l}0.702 * * * * \\
\quad(0.11)\end{array}$ \\
\hline $\begin{array}{l}\text { Year } 2007 \\
(1=\text { yes, } 0=\text { no })\end{array}$ & $\begin{array}{l}2.115^{* *} \\
(1.05)\end{array}$ & $\begin{array}{l}0.081 * * \\
(0.04)\end{array}$ & $\begin{array}{l}0.326 * * \\
(0.12)\end{array}$ \\
\hline Constant & $\begin{array}{l}62.416 * * * * \\
\quad(5.53)\end{array}$ & $\begin{array}{l}4.293 * * * * \\
(0.16)\end{array}$ & $\begin{array}{l}3.923 * * * * \\
(0.26)\end{array}$ \\
\hline Number of observations & 1221 & 1221 & 1221 \\
\hline R-squared & 0.318 & 0.302 & 0.366 \\
\hline F-value & $\begin{array}{c}50.82 \\
(11,1209)\end{array}$ & $\begin{array}{c}50.52 \\
(11,1209)\end{array}$ & $\begin{array}{c}17.40 \\
(11,322)\end{array}$ \\
\hline Prob $>F$ & 0.000 & 0.000 & 0.000 \\
\hline
\end{tabular}

Notes: "BFC-only buyers" are those buyers participating in ILO Better Factories Cambodia (BFC) but not participating in other major MSI, namely, the Fair Labour Association (FLA) or the Ethical Trading Initiative (ETI). "MSI buyers" are those buyers participating in both BFC and the FLA or the ETI.

* Statistically significant at the 0.10 level, $* *$ at the 0.05 level, $* * *$ at the 0.01 level, $* * * *$ at the 0.001 level.

Standard errors are in the parentheses. 